\title{
Arterial Blood Gas Measurement
}

National Cancer Institute

\section{Source}

National Cancer Institute. Arterial Blood Gas Measurement. NCI Thesaurus. Code

C71252.

Measures the acidity $(\mathrm{pH})$ and the levels of oxygen, carbon dioxide, and bicarbonate in the blood. 